\title{
Demographic Profile and Nutrition Status of Women in Rajasthan, India
}

\author{
Tanuja Jukariya ${ }^{1 *}$, Payal Sharma ${ }^{2}$ and Suman Singh ${ }^{1}$ \\ ${ }^{1}$ Department of Family Resource Management, College of Home Science, Udaipur, \\ Rajasthan-313001, India \\ ${ }^{2}$ Aga Khan Rural Support Programme, Muzaffarpur, Bihar, India \\ *Corresponding author
}

Keywords

Demographic

Profile, Nutrition

Status, Rajasthan

Article Info

Accepted:

10 April 2018

Available Online:

10 May 2018

\section{A B S T R A C T}

\section{Introduction}

During the Vedic period women held a respective position in the society and they enjoyed equality with their counterpart. There were no difference between men and women in regard to possession of property and participation in the social and economic activities. They were educated and enjoyed an honoured place in the society about youth and old age. Demographic characteristics are most important variables to measure the socioeconomic development of any geographical unit. Among them literacy is a qualitative aspect of population which is one of the most important indicators of awakening and cultural the main aim of the present study is to examine the demographic profile and nutrition status of the women in the Rajasthan region.

Two thousand years ago, the condition of the female in the society underwent a tremendous change. Male biased law has suppressed the right of equality and it created a new convention that a woman has to be under the authority of her father, husband and son, respectively during childhood advancement; whereas a change in literacy reflects the socioeconomic and cultural transformation of societies (Pant, 2016). 


\section{Materials and Methods}

Rajasthan state is selected for the present study. Historically, the region under the present study has been divided into few divisions Gurjaratra, Bundi, Hadoti and the Dhundhar region Godwar, Marwar, Mewar and Shekhawati region. The study is based on secondary data published by the Census of India, 2011 majorly. The other data has been collected from other reliable secondary sources of information, i.e. newspapers, research/ review paper, articles, short note etc.

The Aravalli Range and the lands to the east and southeast of the range are generally more fertile and better watered. This region is home to the Kathiarbar-Gir dry deciduous forests eco-region, with tropical dry broadleaf forests that include teak, Acacia, and other trees. The hilly Vagad region, home to the cities of Dungarpur and Banswara lies in southernmost Rajasthan, on the border with Gujarat and Madhya Pradesh. With the exception of Mount Abu, Vagad is the wettest region in Rajasthan, and the most heavily forested. North of Vagad lies the Mewar region, home to the cities of Udaipur and Chittaurgarh. The Hadoti region lies to the southeast, on the border with Madhya Pradesh. North of Hadoti and Mewar lies the Dhundhar region, home to the state capital of Jaipur. Mewat, the easternmost region of Rajasthan, borders Haryana and Uttar Pradesh. Eastern and southeastern Rajasthan is drained by the Banas and Chambal rivers, tributaries of the Ganges.

\section{Results and Discussion}

\section{Demographic profile of women}

\section{Distribution pattern}

As per census 2011, population of Rajasthan state is 6.86 crores (exactly $68,621,012$ ) of which male and female are $35,550,997$ and $32,997,440$ respectively. In 2001, total population was $56,507,188$ in which males were 29,420,011 while females were $27,087,177$. The state has recorded $21.44 \%$ growth in last 10 years. The number of males in Rajasthan stands at 35,620,086 while that of females is $33,000,926$. As per the provisional results of the Census 2011, Rajasthan has recorded eighth highest population growth in India.

The native Rajasthani people make up the majority of the state's population. The state of Rajasthan is also populated by Sindhis, who came to Rajasthan from Sindh province (now in Pakistan) during the India-Pakistan separation in 1947. Religion-wise, Rajasthan's population comprises of mainly Hindus, who account for $88.49 \%$ of the population. Muslims make up $9.07 \%$, Sikhs $1.27 \%$ and Jains $0.91 \%$ of the population.

Rajasthan, one of the states which are recognized as EAG (Empowered Action Group) states, has recorded significant fall in decadal population growth rate. Now in 2011, it is $21.44 \%$ and during 1991-2011 the growth rate was $28.33 \%$. There is also a significant fact for Rajasthan in census 2011. Rajasthan is among those states which has the largest number of children aged between 0 to 6 years, estimated at 10,504,916. The state along with Uttar Pradesh (at 29.7 million), Bihar (18.6 million), Maharashtra (12.8 million) and Madhya Pradesh (10.5 million) comprise 52\% children between the age group of 0-6 years in the country.

\section{Literacy pattern}

Literacy is an important indicator of socioeconomic and cultural development. It is regarded as both a means and an end of development (Azim, 2005). Literacy is an essential means for eradicating poverty and mental isolation, for cultivating peaceful and friendly international relations and for permitting the free play of demographic 
process (Chandna and Sidhu, 1980). The Census of India 2011, defines literacy as ratio between literate population ad total population excluding seven years children. In other words, a person aged 7 years and above who can both read and write with understanding in any language has been taken as literate. Female literacy is probably the most enabling tool and weapon in the arsenal of democracy. Literacy emboldens half the populace to successfully demand their rights and achieve gender parity. Literacy is a game-changer in the effort to advance women's standing in the third world. In Women and Literacy, Marcela Ballara (1992) defines literacy as "the apprenticeship for the knowledge needed to cope with everyday needs, including the individual's relationship with the surrounding world'. The importance of literacy need not be stressed-it is an end in itself. Moreover, literacy and schooling are important determinants of economic growth (Barron, 2001) and women's education may be especially important for future growth (Klasen, 2002; world Bank, 2001).

Within societies, education levels are a principal determinant of adult outcomes: if women are disadvantaged in schooling, that disadvantage will ripple through the entire system of gender stratification (Hill and King, 1993). As a result, the Indian literacy rate grew with more than six fold from at the end of British rule in 1947 by 12 per cent to 74.04 per cent in 2011. Literacy rate has been increased from 8.50 per cent in 1951 to 67.06 per cent in 2011. The decadal change in literacy rates as total was 21.9 per cent where by residence, it was 25 per cent in rural areas and 10.9 per cent in urban areas, and by gender it was 20.7 per cent in among males and 23.4 per cent among females.

During recent years, Rajasthan has worked on improving education. The state government has been making sustained efforts to raise the education standard. Rajasthan produces $30 \%$
CA's of India. Rajasthani are topping in IAS, IIT JEE, science Olympiads.

In recent decades, the literacy rate of Rajasthan has increased significantly. In 1991, the state's literacy rate was only $38.55 \%$ (54.99\% male and $20.44 \%$ female). In 2001, the literacy rate increased to $60.41 \%(75.70 \%$ male and $43.85 \%$ female). This was the highest leap in the percentage of literacy recorded in India (the rise in female literacy being 23\%). At the Census 2011, Rajasthan had a literacy rate of $67.06 \%(80.51 \%$ male and $52.66 \%$ female) which is unfortunately less than Cameroon, Egypt and Ghana (Table 2). Although Rajasthan's literacy rate is below the national average of $74.04 \%$ and although its female literacy rate is the lowest in the country, way below the national average of 65.46, and is closely followed by Bihar at 53.33. The state has been praised for its efforts and achievements in raising literacy rates.

In rural areas of Rajasthan, the literacy rate is $76.16 \%$ for males and $45.8 \%$ for females. This has been debated across all the party level except BJP, when the governor of Rajasthan set a minimum educational qualification for the village panchayat elections (Dutta, 2014) (Table 3).

As the first part of this series observed, literacy rates and learning outcomes are some of the lowest in the BIMARU (Bihar, Madhya Pradesh, Rajasthan and Uttar Pradesh) states. By 2020, India will have the world's largest working-age population-869 million-but an India spend analysis of these four states-with $43.6 \%$ of India's school-age population between the age of five and 14-revealed that India is unprepared to educate and train its young population. Rajasthan's overall literacy rate improved 6.6 percentage points over 10 years to 2011, data show, against an all-India improvement of 9.2 percentage points to $74.04 \%$ from $64.8 \%$. 
Table.1 Literacy rates by gender and male-female gap in Rajasthan

\begin{tabular}{|l|c|c|c|c|c|c|}
\multicolumn{1}{|c|}{ Literacy } & $\mathbf{1 9 6 1}$ & $\mathbf{1 9 7 1}$ & $\mathbf{1 9 8 1}$ & $\mathbf{1 9 9 1}$ & $\mathbf{2 0 0 1}$ & $\mathbf{2 0 1 1}$ \\
\hline Female & $\mathbf{7}$ & 10.1 & 14.1 & 20.4 & 43.9 & 52.7 \\
\hline Male & 28.1 & 33.9 & 44.8 & 55 & 75.7 & 80.5 \\
\hline Male-Female Gap & 21.1 & 23.8 & 30.7 & 34.6 & 31.8 & 27.8 \\
\hline
\end{tabular}

Source: Census, 1961, 1971, 1991, 2001 and 2011

Table.2 Rajasthan's education indicators

\begin{tabular}{|l|c|c|}
\hline \multicolumn{1}{|c|}{ Indicators } & Rajasthan & India \\
\hline Literacy Rate & $67.06 \%$ & $74.04 \%$ \\
\hline Net Enrolment Ratio (Grade I to V) & 79.2 & 87.3 \\
\hline Net Enrolment Ratio (Grade VI to VIII) & 67.18 & 74.74 \\
\hline Dropout Rate (Grade I to VIII) & $4.39 \%$ & $4.10 \%$ \\
\hline Student Classroom ratio (Grade I to VIII) & 21 & 27 \\
\hline Pupil Teacher Ratio (Grade I to V) & 17 & 23 \\
\hline
\end{tabular}

Note: Literacy rate for 2011, Dropout rate for 2014-15, other indicators for 2015-16

Source: Census 2011, U-DISE, 2015-16

Table.3 Information regarding sex ratio in Rajasthan

\begin{tabular}{|l|l|c|}
\hline \multicolumn{2}{|c|}{$\mathbf{5}$ Districts Having Highest Sex Ratio in Rajasthan } \\
\hline \multicolumn{1}{|c|}{ S. } & \multicolumn{1}{|c|}{ Name of the District } & Sex Ratio (/1000 male) \\
\hline $\mathbf{1 .}$ & Dungrpur & 994 \\
\hline $\mathbf{2 .}$ & Rajsamand & 990 \\
\hline $\mathbf{3 .}$ & Pali & 987 \\
\hline $\mathbf{4 .}$ & Pratapgarh & 983 \\
\hline $\mathbf{5 .}$ & Banswara & 980 \\
\hline & \multicolumn{1}{|c|}{$\mathbf{5}$ Districts Having LowestSex Ratio in Rajasthan } \\
\hline $\mathbf{1 .}$ & Dulpur & 846 \\
\hline $\mathbf{2 .}$ & Jaisalmer & 852 \\
\hline $\mathbf{3 .}$ & Karauli & 861 \\
\hline $\mathbf{4 .}$ & Bharatpur & 880 \\
\hline $\mathbf{5 .}$ & Ganganagar & 887 \\
\hline
\end{tabular}

Source: Census, 2011

Table.4 Structure of female work participation in Rajasthan

\begin{tabular}{|l|c|c|c|c|c|c|}
\multicolumn{1}{c|}{ Year } & \multicolumn{3}{c|}{ 2001 } & \multicolumn{3}{c|}{ 2011 } \\
\hline \multicolumn{1}{|c|}{ \% Share in Total Workers } & Total & Rural & Urban & Total & Rural & Urban \\
\hline Cultivators & 67.0 & 70.7 & 14.7 & 52.6 & 56.6 & 9.4 \\
\hline Agriculture Labourers & 16.2 & 16.8 & 6.9 & 24.2 & 25.6 & 8.8 \\
\hline Household Industry Workers & 2.8 & 2.1 & 13.6 & 2.5 & 1.9 & 8.8 \\
\hline Other Workers & 14.0 & 10.4 & 64.8 & 20.7 & 15.8 & 73.0 \\
\hline
\end{tabular}


But these improvements hide some of India's sharpest declines in learning levels, particularly in rural government schools. ven though the state's pupil teacher ratio at the primary level, from grade I to V (17), upper primary level, from grade V to VIII (10), and the classroom teacher ratio (21) at the elementary school level (grade I to VIII) is better than the Indian average, learning outcomes have not improved. Reading and arithmetic levels of students between standards II and $\mathrm{V}$ have declined across government and private schools in rural Rajasthan, according to the Annual Status of Education Report 2014 (ASER, 2015). In government schools, the percentage of children in grade II "who can read at least letters" reduced from $80.5 \%$ in 2010 to $56.2 \%$ in 2014. In private schools, the percentage reduced from $93.8 \%$ in 2010 to $81.5 \%$ in 2014. The percentage of children in Rajasthan in grade V, who can "read at least words" declined from $51 \%$ in 2007 to $27 \%$ in 2014 in government schools, while reading levels in private schools declined from $78 \%$ to $64 \%$ over the same period, according to ASER data.

\section{Sex ratio}

In Rajasthan sex ratio (number of females per thousand males) is -928 out of which the urban sex ratio in Rajasthan is 914 and Rural sex ratio in Rajasthan - is 933

\section{Work force participation-workers}

The economic analysis of female labor participation attracted considerable attention since the pioneering works of Mincer (1962) and Cain (1966). The female labor force participation rates increased considerably in the developed countries in recent years. The labor force participation rate plays a increasing trend toward women's participation in the labor market in both developed and developing countries has drawn both social and academic interest resulting in many insightful studies on gender aspects of labor market issues (Ackah et al., 2009). Generals models of gender inequalities (Chafetz, 1984) tend to emphasize the importance of women's economic roles in determining their position in other spheres, from household bargaining to representation in state governance. Empirical research has found that women's labor force participation is associated with less bias against girls in child mortality (Gaur, 2005; Rosenzweig and Schultz, 1982), better health for girls (George and Dahiya, 1998) and with more say in some household decision making (Dharmalingam and Morgan, 1996; Jejeebhoy and Sathar, 2001; Malhotra and Mather, 1997).

Female workers play very important role in agriculture based Indian economy. They participate in farm and non-farm activities besides domestic work. Now the attitude of the society has also changed and working women is not seen with suspicious eyes like earlier. Females constitute about $48.14 \%$ half of the total population in Rajasthan and play a very significant role in the state economy. According to the 2011 census estimates is 29.9 millions, out of which 18.3 millions are males and only 11.6 millions are females. It is more important to highlight that 10.6 millions female are working in rural areas while only 0.98 millions female are engaged as main and marginal workers in urban areas in Rajasthan. Around $77 \%$ of total workers and $18 \%$ of total urban female workers are engaged as cultivators and agricultural labourers (Table 4).

In recent Year women are playing an important role in the economic development. They contribute significant proportion in gross domestic product through actively participating in industries services and in agricultural activities. In India between the 
period 2004-05 and 2009-10 there has been a decline in female employment annually at the rate of $1.72 \%$, whereas Rajasthan is transforming demographically in which population growth slows down, life expectancy increases, per capita income increases and participation of women in labor force increases. The labor work participation rate plays a very important role in determining socio-economic development and growth. It helps in reducing poverty. It shows the supply of labor in the economy and the composition of the human resources of the country. The analysis of the labor work participation is helpful in determining employment policy and policy formulation for human resource development. There have been very few studies done on various dimensions of women work in Rajasthan. Variation in female work participation rates is one of the significant features of state economy of Rajasthan. Female work participation rate has increased from 33.5 percent in 2001 to 35.1 percent in 2011. In urban areas female work participation rate has increased from 9.5 percent in 2001 to 12.0 percent in 2011 and in rural areas it increased 40.6 percent in 2001 to 42.7 percent in 2011.

FWPR of total, rural, and urban for 33 districts of Rajasthan for the period 20012011 it highlights wide gap among districts in female work participation rate and its components. Female workers as cultivation work have been reduced and on the other side the share as agricultural labourers in total female workers have been increased.

This shows that the economic position of females in the state has strengthened and a large share of women worker is engaged in primary sector. Rural women are mostly engaged in agriculture and allied works where they can fulfill their duel responsibility easily and this does not require any special education and training as required for women workers in urban areas. All these factors combines to raise the FWPR in rural areas while in urban areas the reverse happens and FWPR pushed down.

\section{Nutrition status of women}

According to a study conducted by Chaturvedi et al., (2014) The Study was undertaken to assess the nutritional status of 941 adolescent girls, aged 10-18 years belonging to Scheduled Caste communities in rural Rajasthan. Dietary intake was assessed by 24 hours recall method. The dietary intake was compared against ICMR's RDA. It was found that the diets were deficient in calories by 30 to $40 \%$ in proteins by 25 to $37 \%$, by 39 to $55 \%$ in iron and by 10 to $34 \%$ in vitamin A. $78 \%$ of the subjects suffered from various grades of anaemia and $40 \%$ of the subjects had B-complex deficiency.

NFHS (1998-99) found that prevalence of anaemia in Rajasthan and India as shown in Table 1. Singh (2012) show that among EAG states, severe anaemia is highest in Rajasthan whereas moderate anaemia is highest in Jharkhand (69.4\%), Bihar $(68.2 \%)$ and Odisha $(60.9 \%)$ are having the highest percentage of anaemic women among EAG states. Singh, R.K. Life style behavior affecting prevalence of anemia among women in EAG states, India (Population Association of America, Annual Meeting Programme, 2012).

India has $22.8 \%$ households having six or more members, according to the survey. In West Bengal, women get married at an average age of 19.3 years. In Rajasthan, the mean age of marriage of women is slightly better at 19.4 years but it is worst in comparison to other big states. The mean age of marriage in the country is 20 years. In Uttar Pradesh too, women gets married at an average age of 19.4 years. Besides, Rajasthan 
fares worst in women education in age group of 15-17 years. Uttar Pradesh has the highest reproductive span (years) which is 10 years. Following UP, Rajasthan is at the second spot with women having 9.2 years as reproductive span. The national average reproductive span is 6.6 years which is quite lesser than Rajasthan's reproductive span. This has been revealed in the recently released Sample Registration System (SRS) baseline survey 2014.

A series of multi-stakeholder dialogues on health care for women and children organised at five district headquarters in Rajasthan over the past month addressed the issues of "weak supply side" and lack of coordination among different government agencies for framing robust district-level health plans.

The woman, who appears to be only in her late 30s, keeps groaning as she has lost a lot of blood during her mensuration cycle that lasted for a staggering 20 days. State like Rajasthan where maternal mortality rate is 318 , infant mortality rate 55 and child sex ratio is an abysmal 883 girls against 1,000 boys.

Women in India faces number of issues on a regular basis, all states have their own struggles to confront. The condition of women in Rajasthan is pitiable in comparison to other states.

Ours is among the worst states in the country for women. Infamous for child marriages, Rajasthan is among the states having worst sex ratios in the country. Here, women have to collect water from uncovered wells and cook food on firewood. Besides, the desert state also has the worst percentage of girls going to school in 15-17 age group. The women are not well employed too. The reproductive span of women here is second highest in the country. But these are areas where we are improving our performances.

\section{References}

Ackah, C., Ahiadeke, C. and Fenny, A. P. 2009. Determinants of Female Labour Force: Poverty Research Group, Economic and Social Research Council.

ASER. 2015. Trends over Time 2006-2014 (A Supplement to ASER 2014). Inkprint.in, New Delhi. Retrieved from http://img.asercentre.org/docs/Publicati ons/ASER\%20Reports/ASER\%20TOT/ fullasertrendsovertimereport.pdf\#page $=$ 102Retrieved on 5/03/2018.

Azim, S.B. 2005. Missing Females: A Disaggregated Analysis. Economic and Political Weekly. pp. 2074-84.

Ballara, M. 1992. Women and Literacy. Atlantic Highlands, NJ: Zed Books. Barron, P. 2001. The Pattern of Sex Ratios in Singhbhum District, Bihar. Geographical Review of India. 39(1): 30-38.

Cain, N.S. 1966). The woman as final arbiter: a case for the facultative character of the human sex ratio. Journal of Sex Research. 35: 169-175.

Census. 2011. Status of Literacy. Retrieved from http://censusindia.gov.in/2011prov-results/data_files/mp/07Literacy. pdf\#page $=4$ Retrieved on 5/03/2018.

Chafetz, J. I. 1984. Population Geography. Pergamon Press, Oxford, p.14.

Chandna, S. and Sidhu, P. 1980. Social Geography. Rawat Publications, Jaipur.

Chaturvedi, S. U., Trivedi, K. Bhanthi, N. Gnanasekaran, R., and Pandey, M. 2013. Nutritional status of married adolescent girls in rural Rajasthan. The Indian Journal of Pediatrics. 61(6): 695701

Dharmalingam, F. and Morgan, T. J. 1996. Labour Supply Functions in Poor Agrarian Economy. American Economic Review. 69(1): 73-83. 
Dutta, S. 2014. Directorate of Literacy and Continuing Education: Government of Rajasthan. Retrieved from http://indianexpress.com/article/india/in dia-others/rajasthan-governor-fixesminimum-education-qualifications-forpanchayat-polls/ Retrieved on $5 / 03 / 2018$.

Gaur, K. (2005) Occupational Structure in Rural Haryana, Unpublished M.Phil Dissertation, Department of Geography, M. D. University, Rohtak.

George, S. and Dahiya, R. S. 1998. Female Foeticide in Rural Haryana. Economic and Political Weekly. 6: 1291-98.

Hill, J. N. and King, C. P.1993. A Generation of Women: Education in the Lives of Progressive Reformers. Cambridge, MA: Harvard University Press

https://web.archive.org/web/20120323190211 /http://infopiper.com/2012/2011/rajasth an-population-2011-growth-rateliteracy-sex-ratio-in-census-2011/ Retrieved on 5/03/2018.

Jejeebhoy, P and Sathar, V. G. 2001. Female Labour Supply in Rural India- An Econometric Analysis. Institute of Economic Growth, New Delhi.

Klasen, F. 2002. Some Employment and Unemployment Characteristics of Rural
Women: An Analysis of N.S.S Data for West Bengal. Economic and Political Weekly. 13(12): 421-26.

Malhotra, A. and Mather, B. 1997. Inclusive Growth in Education with special reference to Scheduled Castes and Tribes. Journal or Research in Humanities and Social Science. 2: 2328.

Mincer, J. 1962. Labor Force Participation and Unemployment: A Review of Recent Evidence, in R.A. Gorden and M.S. Gorden (eds).

Pant, B. R. 2016. Demographic profile and nutrition status of women in Uttarakhand. ENVIS Bulletin Himalayan Ecology. 24: 101-07.

Rosenzweig, C. and Schultz, S. H. 1982. The Pattern of Sex Ratios in Asia. Economic Geography. 32: 162-76.

Sinha, J. 2015. Rajasthan Population 2011Growth rate, literacy, sex ratio in Census 2011. Retrieved from

U-DISE. 2017. School Education in India. Retrieved from http://www.dise.in/ Downloads/Publications/Documents/UDISE-SchoolEducationInIndia-201516.pdf Retrieved on 5/03/2018.

\section{How to cite this article:}

Tanuja Jukariya, Payal Sharma and Suman Singh. 2018. Demographic Profile and Nutrition Status of Women in Rajasthan, India. Int.J.Curr.Microbiol.App.Sci. 7(05): 1088-1095. doi: https://doi.org/10.20546/ijcmas.2018.705.133 